\title{
POPULAÇÕES RURAIS E ESTUDOS SOBRE A COMUNICAÇÃO NA RECEPÇÃO MIDIÁTICA
}

Ricardo Duarte ${ }^{1}$

\section{Resumo}

No cenário de expansão da eletrificação, da cobertura de internet e do crédito para famílias rurais de contexto popular, os meios de comunicação eletrônicos (internet, celulares, rádio e televisão) aumentam o consumo de mídias no meio rural. Este artigo tem o objetivo de mostrar os principais aspectos teóricos das pesquisas em comunicação articuladas ao meio rural brasileiro, na tentativa de nortear as pesquisas em extensão rural interessadas em desenvolver estudos de recepção das mídias. Apresenta de que maneira a comunicação foi vista dentro dos estudos rurais, o estágio atual dos estudos de recepção e propõe uma abordagem comunicacional da recepção. Neste sentido, encaramos os meios de comunicação eletrônicos longe tanto da percepção da mídia como subjugadora dos sentidos das populações rurais quanto do foco de análise da comunicação apenas em torno do pólo do receptor.

Palavras-chave: Ciências Sociais Rurais, Estudos de Recepção, Mídia e Processos Interacionais, Comunidades Rurais no Brasil.

\section{RURAL POPULATIONS AND COMMUNICATION IN MEDIA RECEPTION STUDIES}

\begin{abstract}
In the scenario of expanding electrification, the internet coverage and credit to poor rural families, the electronic media (internet, mobile, radio and television) increase the consumption of media in the country. This article aims to show the main theoretical aspects of

\footnotetext{
1 Doutorando em Comunicação e Sociabilidade (UFMG), Professor efetivo do Departamento de Comunicação Social da UFV/MG. Mestre em Comunicação Rural (UFRPE). Bacharel em Comunicação Social (UFPE). Membro do Grupo de Pesquisas em Imagem e Sociabilidade do Programa de Pós-Graduação em Comunicação da UFMG.
} 
research in communication that link the Brazilian countryside in an attempt to direct the extension of research interest in the studies of media reception. The paper presents how communication was viewed within rural studies, presents the current stage of "Reception Studies" and proposes a communicational approach the reception. Therefore, we discuss the electronic media away from the perception of the media as oppressive sense of rural populations and the focus of analysis of communication just around the pole receiver.

Key-words: Social Sciences Rural, Reception Studies, Media and Interactional Processes, Rural Communities in Brazil.

\section{INTRODUÇÃO: ARTICULAÇÕES DA COMUNICAÇÃO COM O RURAL.}

Quando se fala de mídias e população rural um dos cenários brasileiro que se apresenta é o proporcionado pela expansão da eletrificação rural através de programas governamentais, a cobertura ainda deficitária de internet no meio rural e o crédito para a habitação rural que tem melhorado a infraestrutura elétrica das propriedades. Com crédito na praça e energia elétrica em casa, as famílias podem adquirir computadores com internet, celulares, mais de um aparelho de rádio e de televisão. Com isto, parece existir a possibilidade de um aumento do consumo de conteúdos midiáticos no meio rural.

Este artigo tem o objetivo de mostrar os principais aspectos teóricos das pesquisas em comunicação articuladas ao meio rural brasileiro, no esforço de contribuir para nortear os estudos em extensão rural que desejam trabalhar com o campo da recepção. Nosso ponto de aterrissagem será o estágio atual das pesquisas de recepção e as possíveis linhas gerais de uma abordagem comunicacional da recepção. Para tanto, sobrevoamos um pouco a história da comunicação na relação com os estudos rurais.

As primeiras experiências de articulação da "comunicação" com o "meio rural brasileiro" parecem se inscrever no início do século $X X$, quando aporta no Brasil a política de difusão de informações do projeto de modernização do campo brasileiro. A ausência de um diálogo junto com as comunidades rurais, característica do projeto modernizador e de suas formas verticais e instrumentais de transferência de informações tecnológicas do emissor onipotente para o receptor passivo, configurou o cenário de debates na história, 
na teoria da extensão rural e da comunicação rural no meio acadêmico brasileiro.

Antes do projeto modernizador, o Brasil precisava de informação para os imigrantes recém chegados ao país e àqueles que seguiam para as regiões rurais. Nisto se justificam as produções informativas realizadas pelas instituições aos novos trabalhadores do campo, que de certa maneira explicavam também a necessidade de aumentar a produção agrícola em função da demanda por alimentos, motivada pela nova população urbana que se formava. A parceria "ciência \& tecnologia" já era tradição na pauta da imprensa especializada brasileira². Em 1938 o Ministério da Agricultura criou o Serviço de Publicidade Agrícola ou Serviço de Informação Agrícola ${ }^{3}$. Até 1950, enquanto o Serviço informou o agricultor sobre tempo, lavoura, plantio e colheita, os meios de comunicação se encarregaram das notícias sobre agricultura em geral e os líderes sindicais e comunitários entravam em contato com o agricultor (BORDENAVE, 1983).

A chegada da política de modernização do campo, financiada por organismos internacionais, foi encarada pelas instituições brasileiras como positiva ao país, considerando a necessidade do aumento da produtividade agrícola através da adoção de "novas" máquinas e técnicas. Mas o descompasso entre o grande projeto e o pequeno agricultor - que desenha o fosso socioeconômico e cultural entre o moderno/urbano e o tradicional/rural, nos anos de 1940 e 1950 - impediu uma política de proximidades que possibilitasse a troca de saberes entre os conhecimentos técnico-científicos e o senso comum. Tal política vertical do projeto não levou em conta as alterações nas tradições, nos saberes da cultura do plantio, nos hábitos da família da pequena agricultura. Tanto a difusão das inovações tecnológicas quanto a imposição da adoção de novas máquinas agrícolas provocavam um contraste abrupto com o saber popular desta maioria da população rural em suas tradições técnicas e costumes próprios de sua forma de vida rural, pois não levou em conta a heterogeneidade do rural

\footnotetext{
${ }^{2}$ A Revista Imperial do Instituto Fluminense de Agricultura (IIFA), vinculada ao Império em 1869, proclamou a utilização da ciência para melhorar a produção agrícola. Mais tarde, com a chegada dos estrangeiros ao país, a revista "O Immigrante", publicação da Secretaria de Agricultura de São Paulo, editou a revista em 1908 em seis idiomas e em 1917 alcançou a soma de 415 mil publicações (BORDENAVE, 1983).

${ }^{3}$ No Brasil, em 1935, durante o governo Getúlio Vargas, surge o programa de rádio "A Hora do Brasil", que em 1971 no governo militar passou a se chamar "A Voz do Brasil". O programa é considerado o mais antigo em veiculação no rádio brasileiro. O programa foi um dos primeiros exemplos de difusão de informações, pois era transmitido diariamente pelas rádios para todo o território nacional.
} 
brasileiro. As máquinas modernas norte-americanas, a força política das instituições financiadoras do projeto modernizador (como a Fundação Rockefeller ${ }^{4}$ e a dependência do Brasil a esta transferência de tecnologia dos EUA para dar início ao desenvolvimento da produtividade rural, impactou a vida destas pessoas, que viviam naquela época em meio ao desamparo econômico, social e educacional.

Uma política de proximidades com a vida rural dos sujeitos de contexto popular rural não interessava aos institutos promotores do projeto modernizador. Assim o projeto foi político tanto pela espetacular mensagem da tecnologização que pré-definia uma ordem imposta à forma de vida simples das pessoas do campo como pelo aspecto da distância que lhe era inerente (o chamado "visível desencontro" salientado por Luis Ramiro Beltrán) em relação ao espaço público cotidiano do agricultor, um lugar onde deveria ser configurada e legitimada a política de modernização. Como se vê, a política à qual nos referimos não está restrita ao exercício do poder pelos organismos internacionais, governos e associações ou à luta por esse poder, mas se concretiza essencialmente na esfera onde se partilham as experiências, os afetos, as decisões deliberadas e objetos comuns. A inexistência desse espaço (tanto pré-político quanto político) produziu no terreno da recepção deste projeto pessoas sem uma palavra comum, oficializando linhas de discursos institucionais sobre as tecnologias para o campo como único caminho a ser seguido para o desenvolvimento rural, deixando as esferas de autoridade com a palavra e o agricultor sem voz.

A política vertical dos organismos internacionais tem origem no pragmatismo político dos EUA, que desenvolveu a estratégia de transferência do projeto político-econômico estadunidense no pósguerra ${ }^{5}$ a partir do envio do seu excedente tecnológico para os países da América Latina.

4 Os grandes patrocinadores da Extensão Rural no Brasil foram o Instituto Interamericano para Assuntos da América (IIAA/EUA), a Fundação Ford, OEA, Bird, Fao e em especial a Fundação AIA, da família Rockfeller e maior exportadora de café do Brasil, responsável pela criação da ACAR Minas Cereais, a Ancar no Nordeste e a Abcar. A AIA criou a Agroceres e a Cargill (São Paulo e Paraná) e patrocinou a maior experiência em extensão rural no Brasil em Santa Rita do Passo Quatro e São José do Rio Preto/SP, entre 1947 a 1956. Essa experiência ocorreu sob a coordenação do prof. John B. Griffing, da ESAV, que trabalhou com a participação comunitária dos pequenos produtores dessas regiões (FIGUEIREDO, 1981).

${ }^{5}$ Durante a II Guerra os EUA desenvolveram no Brasil alguns programas destinados à área da agricultura, por conta da própria economia de guerra: o Programa de Produção de Alimentos e o Programa da Borracha. A Guerra Fria proporcionou um desenvolvimento científico e tecnológico considerável na agricultura brasileira em função 
As bases teóricas que fundamentaram esta difusão de tecnologias para o campo estavam na chamada Mass Communication Research (MCR), escola que foi hegemônica na pesquisa em comunicação nos EUA, entre 1920 e 1960. Em especial a área da "comunicação e persuasão", que constituiu o fundamento teórico da campanha de adoção das tecnologias no campo brasileiro. A corrente teórica dos "Estudos dos Efeitos" do MCR adotava o modelo da "Teoria Hipodérmica", que olhava a sociedade industrial do século XX como uma grande massa disforme de indivíduos sem relações interpessoais, sob a influência das teorias behavioristas de estímulo-resposta. Daí a ideia disseminada sobre os meios como sendo onipotentes na sua função de provocar efeitos de ação direta na sociedade, sem a interferência de outros fatores, como uma "agulha hipodérmica".

A partir dos anos de 1940, a "abordagem da persuasão" superou a "teoria hipodérmica" e promoveu estudos empíricoexperimentais sobre fenômenos psicológicos individuais. Enquanto a "hipodérmica" falou em manipulação, a "persuasão" abordou mais a influência que se definia por processos psicológicos entre a ação dos meios de massa e seus efeitos na estrutura do sistema social. No entanto, esta abordagem ainda carregou consigo a concepção de causa-efeito, bem como a mesma negligência quanto às relações interpessoais dos indivíduos (ARAÚJO, 2001).

Em 1958, as pesquisas sobre "Comunicação para o Desenvolvimento" de Daniel Lerner e Wilbur Schramm (1973), e De Sola Pool (1963), visualizam a saída do subdesenvolvimento por meio da passagem linear da sociedade tradicional (selvagem, primitiva e com todos os seus defeitos) para a moderna (civilizada, tecnológica e com todas as vantagens). Essas pesquisas conceberam os meios de massa como estratégicos para 0 desenvolvimento urbano e rural e estiveram de acordo com a noção de transferência de informação desenvolvida por Harold Lasswell, da "Corrente Funcionalista" da MCR. Tal corrente caracterizou a comunicação enquanto um processo de transmissão de ideias, emoções, habilidades pelo uso de símbolos e palavras, quadros e cifras (BERELSON e STEINER, 1964); a comunicação persuasiva como uma fonte que influencia o destinatário mediante manipulação de sinais alternados, transferidos pelo canal que os liga (OSGOOD, 1961).

do chamado plano "Ponto 4" na América Latina: uma estratégia de presença dos EUA na região (FIGUEIREDO, 1981). 
Entre as orientações dos efeitos (LAZARSFELD e MERTON) ${ }^{6}$ e das funções (Laswell) existiu uma coerência mínima em torno da eficácia da propaganda política, da utilização comercialpublicitária e da influencia dos meios de comunicação nos comportamentos e no quadro de valores sociais. Em especial, a orientação das funções concebeu a comunicação como transferência de informação e processo de persuasão (no caso, das ideias do desenvolvimento a partir da adoção das novas tecnologias), e filiouse à perspectiva da "Comunicação para o Desenvolvimento". O processo psicológico compreendido entre a ação dos meios e seus efeitos, restrito a um sistema de signos da modernidade, obedeceu a uma ordem ótima da mensagem de forma a atender às finalidades persuasivas do projeto modernizador e interferir nas estruturas do sistema social. O que menos importou nisso tudo foi o sujeito que recebia essas mensagens.

A teoria da comunicação do MCR foi testada na prática no meio rural brasileiro, mas revelou seu insucesso quanto ao aspecto sociocultural. Ela foi utilizada em novas pesquisas sobre estratégias de difusão de tecnologias para o homem do campo, enquanto a extensão rural produzia a transferência de informações e o agricultor aplicava o modelo. Aos poucos, junto com a falta de continuidade que marcou o insucesso dos projetos de modernização do campo brasileiro, o agricultor também começou a ser visto como "maleducado", "resistente", "refratário" e ainda com defasados conhecimentos sobre agricultura. A pesquisa norte-americana da MCR se desenvolveu também por conta da presença de uma posição subalterna assumida pelos governos latino-americanos, pois os países em desenvolvimento, antes dos anos de 1970, já sabiam que suas vidas política e econômica eram dependentes dos países desenvolvidos (BELTRÁN, 1981).

As críticas ao difusionismo, nos anos de 1970, surgiram em especial do Centro Internacional de Estudios Superiores de Periodismo para América Latina (Ciespal), alertando para a transferência vertical e hegemônica dos conhecimentos, geradora de

\footnotetext{
${ }^{6}$ Nos anos de 1940 e 1950, o sociólogo Paul Lazarsfeld, partindo do paradigma funcionalista, começou a identificar que as pessoas vivem em relações nos grupos, nas categorias sociais, enfatizando as mediações que caracterizam o consumo dos meios de comunicação. A mídia não atua diretamente, como na teoria hipodérmica da manipulação, pois a influência dos meios é filtrada pelos grupos intermediários e pelos "líderes de opinião", configurando o conceito de fluxo em duas etapas, two-step flow: tais pessoas seriam os melhores canais para influenciar a massa disforme. O importante, aí, é que as pesquisas de Lazarsfeld sublinhou que os receptores se relacionam nos contextos sociais e a influência da mídia não pode prescindir da incorporação dos fatores extra-mídia (FRANÇA, 2003).
} 
conflitos nas sociedades por conta da forma autoritária de adoção das práticas extensionistas vinculadas às formas de controle e poder (BELTRÁN, 1976, BORDENAVE, 1976, NUNES, 1977). Em resposta aos relatórios preconceituosos dos organismos internacionais em relação ao agricultor brasileiro, os pesquisadores do Ciespal afirmaram que o difusionismo, em parceria com a comunicação instrumental mercantilista e mecanicista, servia à manutenção do status quo. Começam a denunciar os meios de massa como domesticadores da realidade e subjugadores dos sujeitos. Mas por apenas desenvolver uma visão anti-difusionista e denunciar o vínculo dos meios de massa com o poder político, as pesquisas de crítica ideológica não apresentaram uma saída à visão instrumental e representacionista dos meios de comunicação.

A primeira grande crítica ao difusionismo partiu do pesquisador norte-americano David Berlo, no texto "Communication theory and audiovisual instruction", quando contrapôs o difusionismo à "teoria do balde": as ideias codificadas dentro de um "balde" eram derramadas, até esvaziar, diretamente no ouvido do receptor (BÉLTRAN, 1981). A crítica de Berlo (1963) fez Daniel Lerner rever a concepção linear da comunicação e Wilbur Schramm apontar equívocos no modelo da transmissão de informações (LERNER e SCHRAMM, 1973), embora sem abrir mão do paradigma tradicional unilinear R-M-C-R. A segunda grande crítica surgiu no Brasil, em 1969, por Paulo Freire e sua compreensão da educação como instrumento de libertação das massas da opressão das elites. Freire trouxe novos olhares para velhos problemas, a partir do paradigma dialógico-participativo. Apesar da visão de Freire ter sido um divisor de águas na pesquisa e na prática da comunicação em contextos populares, o novo paradigma requenta a visão anti-difusionista das pesquisas de crítica ideológica, sem apresentar saída à visão instrumental e representacionista dos meios de comunicação. Com isto, a comunicação vertical das instituições foi apropriada por visões partidárias da esquerda política e pelos pesquisadores, que não souberam olhar criticamente para o modelo participativo ${ }^{7}$, aplicado aos estudos de comunicação, e lhe oferecer outras alternativas ao longo do tempo.

\footnotetext{
${ }^{7}$ A natureza da comunicação horizontal, para Beltrán (1981), está em um processo de interação social inerentemente democrático, onde se trocam símbolos e experiências de maneira livre e sob condições igualitárias de diálogo e participação. Tais considerações, na prática, não se concretizam: a atuação controladora do Estado e a influencia dos grupos de advocacys nos "diálogos políticos" põem em dúvida a existência de condições igualitárias de diálogo e participação dentro do processo de comunicação horizontal.
} 
Aos poucos, algumas pesquisas começam a se interessar por esse "campo da recepção" das informações dos meios de comunicação. A partir dos anos de 1970, trabalhos surgiram na sociologia e na antropologia, sob influência da teoria crítica, da semiologia e da teoria dos efeitos, dando muita ênfase à ideologia das mensagens; na comunicação, sob influência da participação dialógica freireana através do programa de Leitura Crítica da Comunicação (LCC), organizado pela União Católica Brasileira de Comunicação Social (UCBC) (JACKS, et al, 2010).

Nos anos de 1980, as crescentes críticas ao difusionismo e o crescimento do modelo horizontal incorporaram o conceito de "hegemonia" ${ }^{\circ}$ e influenciaram estudos sobre comunicação balizados em investigações sobre "contra-informação", algo bem específico à visão de mundo da época. Por volta de 1987, Jésus Martín-Barbero lança a antológica obra Dos meios às mediações, sugerindo uma passagem do instrumental dos meios de comunicação para análises que vinculassem comunicação e cultura. Esta obra influencia toda a pesquisa em comunicação e os estudos de recepção, nos anos de 1990 em diante.

No âmbito da comunicação articulada ao meio rural, Bordenave (1993) chamou a atenção para uma comunicação não somente vinculada a diálogos instrumentais (técnicos ou educativos), mas associada a "diálogos políticos". Em tais diálogos, a Comunicação Rural seria responsável por levar as demandas dos agricultores à produção de políticas públicas; no plano mais horizontal, continua o diálogo com os agricultores sobre assistência técnica e extensão rural; e no plano instrumental e vertical, cursos de educação à distância. Na prática, enquanto as organizações nãogovernamentais e entidades utilizaram os tais "diálogos políticos" para disseminar ideologia política institucional, a assistência técnica e extensão rural continuaram a enxergar os meios de comunicação de massa como instrumentos para suas práticas assistencialistas e extensionistas.

Por essa alça, o campo da pesquisa em comunicação articuladas ao meio rural ${ }^{9}$ adentrou um complexo e indeterminado

\footnotetext{
${ }^{8}$ A Comunicação Rural, ainda sob influência da força dos discursos de dominação política e econômica, começa nos anos de 1980 a considerar o conceito de hegemonia, na perspectiva dos estudos culturais de Antonio Gramsci. O enfoque da preocupação de Gramsci nas pesquisas em Comunicação e Cultura está na compreensão da tradição e da modernidade no Terceiro Mundo a partir dos movimentos das classes sociais e dos governos na contemporaneidade, pois o que estaria em jogo era a comunicação humana, particularmente nos setores sociais em que o autor chama de "subalternos".

${ }^{9}$ Entre os anos de 1968 e 1975 surgiram os primeiros cursos de pós-graduação em Extensão Rural na UFV (antiga Esav), na UFSM/RS e, em 1979, na UFRPE (em 2003, o
} 
espaço de questões incompletas, pautadas sempre nas discussões sobre o tradicional e sua relação com o moderno, ancoradas no modelo da comunicação freireano de visão anti-difusionista e que, quando utilizava os estudos de recepção, buscava produzir compreensões instrumentais e representacionais acerca da relação dos meios de comunicação e o desenvolvimento rural. Um dos problemas que impediram o avanço além destas armadilhas teóricas e metodológicas estaria nas discussões sobre comunicação rural e extensão rural sempre descoladas dos debates sobre recepção dos meios de comunicação desenvolvidos por fóruns avançados como a Compós (Associação dos Programas em Pós-Graduação em Comunicação). Isto fez com que, até hoje, houvesse uma indefinição ou pouca atualização sobre o conceito de comunicação rural, fazendo com que os estudantes de pós-graduação recorram ao conceito clássico de Bordenave (1983). As poucas definições mais atuais não dão conta de explicar os atuais fenômenos comunicativos em face da atual mediatização tecnológica.

No entanto, vale salientar que os anos de 1990 foram importantes para as pesquisas em comunicação com o objeto de estudo na população rural, pois algumas investigações lançaram nova luz sobre o campo. A consolidação do conceito de "ação local" promovido pelas ONGs ajudou nas discussões posteriores sobre a questão ambiental, tema da pauta atual dos programas institucionais para o desenvolvimento rural, como também de algumas pesquisas em extensão rural ${ }^{10}$. Também os tais "diálogos políticos" de Bordenave (1993) foram criticados com relação a efetiva participação dos agricultores, o que abriu espaço para uma preocupação com a produção de sentidos dos agricultores (TAUK SANTOS, 1994) ${ }^{11}$,

\footnotetext{
Mestrado em Comunicação Rural se transforma em Extensão Rural e Desenvolvimento Local). A primeira tese doutorado sob a perspectiva freireana foi produzida por Luis Ramiro Beltrán, em 1972. Outras pesquisas importantes foram surgindo: João Bosco Pinto (1980), José Graziano da Silva (1981), Juan Díaz Bordenave (1983) e uma das primeiras teses de doutorado na ECA/USP sobre comunicação rural, em 1988: "Questão Agrária e Comunicação Rural no Brasil", de Walmir de Albuquerque Barbosa (Callou, 2001). Nesse mesmo período, vale a pena salientar que trabalhos vindos das Ciências Sociais viraram clássicos nos cursos de comunicação ao abordar o tema da televisão: Sérgio Miceli, "A Noite da Madrinha" (1971); Luiz Augusto Milanesi, "O paraíso via Embratel" (1977); e Carlos Eduardo Lins e Silva, "Muito além do Jardim Botânico" (1984).

${ }^{10}$ Sobre essa preocupação das pesquisas em comunicação com a comunicação rural e com a questão ambiental, confira Braga e Kunsch (1993) e artigos que balizaram as discussões do $11^{\circ}$ e do $13^{\circ}$ Congresso Brasileiro da Intercom (Revista "Comunicação e Sociedade - Ecologia", ano XI, n 19, São Bernardo do Campo/SP: Editora do Instituto Metodista de Ensino Superior - Edims/IMS, 1993,140p).

11 Nos anos de 1990, Maria Sallet Tauk Santos (UFRPE) orientou alguns estudos de recepção para analisar a produção de sentido dos sujeitos de contextos rurais (receptores) em face das propostas dos programas governamentais (emissores),
} 
percepção auxiliada pela visão do receptor como sujeito ativo no processo comunicacional (Sousa, 1995) que se juntava ao contexto das "novas ruralidades" ou "o novo espaço agrário" brasileiro (CAMPANHOLA e GRAZIANO, 2000) ${ }^{12}$. Estes aspectos desenvolveram tendências de debates no âmbito acadêmico e na discussão sobre políticas públicas, ganhando espaço nos media.

A questão do meio ambiente e das atividades não-agrícolas (o crescimento do setor de serviços no meio rural) motivaram as discussões dos pesquisadores e dos extensionistas, pois havia a necessidade de empoderar os sujeitos à promoção do desenvolvimento rural sustentável, tendo em vista um rural que se esvaziava de agentes promotores da preservação ambiental e desenvolvimento local $^{13}$. Cresceram, então, as críticas à efetiva participação da comunidade nos projetos, a não ocorrência do "diálogo" entre instituição e comunidade, a falta de continuidade dos projetos e o descompasso de expectativas. Neste sentido, os estudos de recepção ${ }^{14}$ nos anos de 1990 foram utilizados no meio rural para entender a produção de sentidos dos sujeitos e, com isso,

indagando se os tais "diálogos políticos" dariam conta das expectativas simbólicas dos agricultores nos encontros com os extensionistas e técnicos.

${ }^{12}$ A pesquisa influenciou sobremaneira a perspectiva dos estudos em Comunicação Rural e Extensão Rural. Nasceu da parceria entre os estudos tradicionais desenvolvidos por órgãos técnicos econômicos e as investigações de perspectiva acadêmica produzida pelos institutos de economia nas universidades brasileiras, atualizando a questão do meio rural brasileiro na contemporaneidade. A nova caracterização da população residente no meio rural brasileiro sugeriu pensar o meio rural brasileiro para além das atividades estritamente agrícolas e agropecuárias. Graziano (1993, p.11) sugere ampliar "a velha noção de rural para além das atividades produtivas tradicionais (tais como culturas e criação de animais) e incluir no espaço agrário a produção de serviços (tais como lazer, turismo, preservação do meio ambiente, etc) e de bens não-agrícolas, como por exemplo moradia, artesanato, incluindo aí também as formas modernas de trabalho a domicílio, tão comuns nos países desenvolvidos".

${ }^{13}$ Este esforço dura até hoje, mas o Censo IBGE 2010 mostrou que a população rural ainda é significativa (29 milhões de pessoas) e o que preocupa seria a redução do número de jovens rurais (hoje em 7.807.627). Os números são maiores que em países como México, Chile e Argentina, onde as indústrias e as grandes áreas rurais abandonadas se multiplicam. Isto mostra que a realidade brasileira sempre se caracterizou pela heterogeneidade das propriedades rurais, da diversidade da produção agrícola, dos investimentos e dos costumes de vida dos sujeitos de contextos rurais (NAVARRO, 2012).

${ }^{14}$ Os estudos de recepção se dedicam a investigar o lugar do receptor no processo comunicativo na perspectiva de um sujeito ativo, não indefeso, diante da mensagem do emissor, a partir do paradigma das mediações culturais e do conceito de hegemonia dos estudos culturais britânicos. Tradicionalmente são estudos midiáticos, ou seja, estudos de audiência e da recepção de programas de rádio, tevê e públicos de jornal impresso. Para uma visão sobre os estudos de recepção nos anos de 1990 até 2010, confira os trabalhos da pesquisadora Nilda Jacks (2008, 2010, 2011, 2012). 
funcionaram como instrumento de pesquisa importante às políticas públicas mais adequadas às suas expectativas.

Em meio a este cenário problemático e as importantes discussões e questionamentos sobre o papel da comunicação no meio rural, nos anos de 1990 a academia discutiu o conceito de rural em função da perspectiva trazida pela noção do chamado "novo espaço agrário". Tal perspectiva trouxe de volta o debate em torno da homogeneização do rural, mas também dos antagonismos dicotômicos e da heterogeneidade do rural. Esses debates trouxeram novos olhares à comunicação articulada ao meio rural.

\subsection{O rural e sua condição rurbana}

Em geral, o rural sempre foi percebido pelo senso comum a partir da comparação com o mundo urbano, enquanto que as visões acadêmicas e institucionais observaram o rural pelas delimitações analíticas e normativas. As instituições sempre enquadraram o conceito em sistemas terminológicos e classificatórios de acordo com os interesses e objetivos do uso prático dos termos. O Instituto Brasileiro de Geografia e Estatística (IBGE), por exemplo, considera área rural toda a região externa ao perímetro urbano legal, e utiliza para tal argumento uma grande fonte de dados, de conteúdos estatísticos e contagem populacional. Nas universidades, onde o conceito de rural se desenvolveu, algumas correntes de pensamento ajudaram no debate e nos delineamentos teóricos.

No início do século XX, a sociologia norte-americana (que tomou como referência os estudos clássicos sobre comunidade e sociedade de Ferdinand Tönnies) definiu o rural em oposição ao urbano (teoria dicotômica). Esta perspectiva foi questionada por autores que defenderam a homogeneização do rural com o urbano na teoria do continuum (SOROKIN; ZIMMERMAN; GALPIN, [1929] 1986).

O rural passou a ser encarado como auto-explicativo, uma percepção que brotou das definições clássicas que caracterizaram a sociedade rural: território com dimensão específica restrita às atividades agrícolas e à economia; lugar da produção de alimentos através da criação de plantas e de animais. A esta atividade econômica se vincularam todos os outros traços de um rural visto enquanto o contato constante com a natureza. Por conta deste contato próximo com os organismos naturais, o rural adquiriu a característica de ser um ambiente instável das forças da natureza. Sua população seria mais tradicional do que urbana, com pouca mobilidade social, menos lazer e mais pessoalidade entre seus 
moradores (SOLARI, 1979). As definições do rural, nos anos de 1970, estiveram atreladas às estruturas organizacionais agrárias da sociedade rural.

Nos anos de 1980, a produção acadêmica no campo da sociologia rural foi marcada por estudos esparsos e pela dificuldade de definir melhor novos conceitos. Vários estudos se debruçaram sobre a realidade dos sem-terra, dos atingidos por barragens, dos assentados rurais, sempre na busca da compreensão dos processos e dos movimentos sociais em curso naquele período. Nesta fase, os pesquisadores sociais identificaram problemas e questões comuns em diversas áreas do conhecimento, o que fez surgir outras temáticas, novos conceitos e categorias, permitindo diferentes recortes empíricos, propostas epistemológicas, metodológicas e outras discussões, tais como identidade social, cidadania, relações de gênero, violência e ecologia (SIQUEIRA; OSÓRIO, 2001).

Em especial, os temas marcados pelos discursos relacionados ao meio ambiente e a ecologia produziram um pensamento em torno da sociologia ambiental que representou um campo de especialização oponente da sociologia rural. Enquanto se desenvolveram as questões em torno da interação sociedade e meio ambiente, as discussões cresciam sobre o desenvolvimento sustentável, tanto na academia quanto entre os movimentos sociais (SIQUEIRA; OSÓRIO, 2001).

Nos anos de 1990, voltou a ganhar força a teoria do contínuo rural-urbano, a ideia de que as demarcações territoriais entre as áreas tendiam a se dissolver por causa do avanço da urbanização. Por conta do desenvolvimento tecnológico, das atividades não-agrícolas, da transmissão de informação, dos meios de transporte e do processo geral da globalização, a urbanização dos rurais transformaria em "uma coisa só" os universos do ruralnatureza e do urbano-industrial (GRAZIANO DA SILVA, 1993,1996, 1997; TOLEDO, 1998).

Em oposição a esta perspectiva, outros estudos observaram as dinâmicas da pluriatividade, as novas sociabilidades e as identidades que questionaram a submissão do rural ao urbano (CARNEIRO, 1998, 2005; WANDERLEY, 2001; PONTE, 2004). A ideia de contínuo rural-urbano mereceu reflexão, dada as realidades rurais altamente distintas uma das outras (CARNEIRO, 1998), especialmente no Brasil.

Outra perspectiva mais atual, o estudo do rural pela abordagem territorial, também defendeu a ideia contrária ao fim do rural (VEIGA, 2002, 2004; BLUME, 2004), questionando a classificação normativa dos institutos de pesquisa: a cada censo 
demográfico, os institutos apresentaram dados percentuais sobre a população rural, indicando um suposto esvaziamento do campo. No entanto, nestes levantamentos estatísticos havia alguns equívocos: as ocas indígenas no Brasil, por exemplo, foram consideradas como "área urbana", pois algumas se situavam no interior do perímetro urbano da sede do município (VEIGA, 2002).

Longe destas classificações arbitrárias, dos antagonismos dualísticos, bem como das perspectivas apocalípticas sobre o rural, este texto se filia a perspectiva da pesquisadora Maria José Carneiro (1998), mas propõe como percepção assessória que cada cultura rural seja vista também na sua relação com a área urbana mais próxima ou o urbano-referência. Com isto, abrimos espaço para observar as mesclas do rural "tradicional" de uma comunidade com os traços do mundo urbano moderno, bem como enxergarmos uma condição rurbana no meio rural.

As distâncias entre o campo e a cidade já não são tão largas como antigamente por conta de um fluxo de informações cada vez mais intenso entre as regiões. Por isto que a informação nos parece ter sido o combustível à formação deste rurbano. $A$ condição rurbana significa uma forma de vida rural que já diminuiu bastante seu estranhamento na relação com o mundo urbano. Cremos, portanto, que talvez não exista condição rurbana no rural sem a presença e a influência da informação do mundo urbano. Neste sentido, não seria difícil pensar que a mídia tem um papel importante na aproximação do rural com o urbano, na construção de uma mescla rurbana nos costumes, nos comportamentos, na economia, na sociedade.

Foi este fluxo de informações (via transferência oral de informações, relações face a face, por cartas, telefone, etc) que permitiu a troca de experiências entre as pessoas, transformando o rural tradicional em um rural mais contemporâneo, permitindo mais visibilidade do rural além das representações do "velho" e do "atrasado", mas igualmente como bucólico, sossegado, lugar do contato com fauna e flora, lugar da medicina natural, dos spas relaxantes junto à natureza, do lazer rural (pescarias, esportes de montanha), da cura espiritual (através da energização pelas pedras, dos banhos de ervas, da meditação em contato com a natureza) e da alimentação saudável. A fuga dos citadinos da cidade e o retorno dos migrantes para o rural valorizaram aos olhos da mídia o próprio ambiente rural, que mostrava o estilo de vida urbano como estressante e de pouca qualidade de vida. Por outro lado, as atividades não-agrícolas, em algumas regiões, mudaram algumas regiões rurais para um aspecto "moderno": o trabalhador rural 
também trabalha como guia turístico; o ordenhador de leite virou recepcionista do hotel rural; o vaqueiro passou a garçom de restaurante pesque-pague. $E$ alguns cenários também mudaram: a plantação de milho foi substituída por um parque recreativo; o lugar de pastagem do gado substituído por um parque tecnológico; o comércio local se ampliou, novos sujeitos circularam e cresceu o emprego no setor de serviços tipicamente urbanos.

Essa aproximação do rural com o urbano produziu áreas rurais urbanizadas, crescimento das atividades não-agrícolas, transformações parciais no mundo rural, industrialização, mas igualmente resistência das tradições e modos de vida rurbanizados. Em alguns lugares, apesar das pessoas valorizarem o rural, ter vontade de continuar as atividades agrícolas ou empreender alguma atividade não-agrícola em sua propriedade, a condição socioeconômica empurra esses indivíduos para trabalhar e estudar na sede urbana do município. A falta de motivação pelo trabalho na roça, a insegurança da atividade na agricultura, as linhas de crédito que não atendiam suas expectativas, aliados aos problemas familiares, ao relevo da propriedade, ao manejo inadequado de culturas e a extinção da escola rural foram alguns fatores que contribuíram para o surgimento de uma condição rurbana do jovem rural ${ }^{15}$.

O jovem rural que já passou da idade escolar e não ingressou em alguma universidade ou instituto tecnológico continua a morar na roça e trabalha, por exemplo, como motoboy na sede urbana do município. Para melhorar a propriedade ou sair definitivamente do rural, o jovem adota uma condição rurbana

\footnotetext{
${ }^{15}$ O conceito de "rurbano" foi acionado pela primeira vez pelo sociólogo Gilberto Freyre (1982) que, através de vários escritos - "Palavras às Professoras Primárias de Pernambuco em 1956", "Novas Reflexões em Torno de uma Reorientação para o Desenvolvimento Brasileiro: a Rurbana" e "Da Ecologia à Rurbanização: Considerações Gerais um Tanto Desordenadas" - procurou desenvolver a tese do estilo de desenvolvimento a partir da paisagem de equilíbrio interpretativo dos extremos do atraso/rural e do moderno/urbano, sendo possível de realização a partir da vontade política dos homens públicos engajados no social (SANTOS, 2001). Mas a "condição rurbana" na qual nos referimos parece ser diferente do pensado por Freyre, pois reflete a trajetória de vida das populações rurais que sempre dependeram do urbano para vender os produtos, adquirir conhecimentos, comprar mercadorias e, em muitos casos, ter saúde, emprego e renda. A urbanização de áreas rurais e o crescimento das atividades não-agrícolas também ocorreram de maneira desigual, mas no geral os povoados, as vilas e os distritos e municípios rurais ainda conservam problemas de infra-estrutura urbana, de saúde e acesso a informação: entre um distrito rural e outro de uma mesma micro-região, existem várias discrepâncias de classe social; em uma mesma vizinhança, uma família rural pode possui bom sinal de internet e a outra não; de um vilarejo para o outro, o sinal do celular ou de uma emissora de rádio pode ser forte ou inexistente.
} 
temporária, em que mora no rural e busca renda na área urbana, ou permanente, quando o jovem já se acostumou nesta vida entre o rural e o urbano.

Pensando, portanto, a importância das mídias como fomentadora de informações que diminuem o estranhamento do rural na relação com o mundo urbano e, consequentemente, alimentam esse ambiente rurbano, lembramos que as telenovelas e os telejornais (dois gêneros preferenciais entre os habitantes do rural) pautam assuntos e temas sociais que, em certa medida, estimulam a adoção de regras, padrões e valores entre as populações rurais. Os programas televisivos (a televisão ainda seria o veículo mais consumido no meio rural) alicerçam todos os dias um espaço semântico de compreensão do mundo, mas também um campo prépolítico, onde temas públicos fazem as pessoas pensarem, por vezes temas que posteriormente alcançam o universo do campo político das deliberações locais. E as pessoas comentam os assuntos das mídias ou pelo menos emitem opinião sob influência de tais conteúdos, nos espaços de sociabilidade. Por este caminho se desenha a importância dos estudos no campo da recepção.

\section{ESTUDOS DE RECEPÇÃO NO DIVÃ}

Sob a influência política e teórica dos autores fundadores dos estudos culturais britânicos ${ }^{16}$ e a penetração do conceito de hegemonia os estudos de recepção no Brasil, entre os anos de 1980 e 1990, desenvolveram algumas abordagens teórico-metodológicas com ênfase na perspectiva latino-americana.

Destacam-se as correntes conhecidas como Consumo Cultural, desenvolvida por Néstor García Canclini; Frentes Culturais, coordenada por Jorge González no Programa de Estudios sobre las Culturas Contemporaneas (Colima/México); Recepção Ativa, desenvolvida no Centro de Indagación y Expresión Cultural y Artística (Ceneca/Chile) sob a coordenação de Valério Fuenzalida e Maria Elena Hermosilla; Uso Social dos Meios, concebida por Jesús Martín-Barbero; e Enfoque Integral da Audiência, proposta teóricometodológica de Guillermo Orozco, desenvolvida no Programa

\footnotetext{
${ }^{16}$ Nos limites deste artigo não iremos dissertar de forma mais minuciosa sobre os estudos culturais britânicos, apenas ressaltando que a importância política dos estudos se vincula às origens de um aldeão (Raymond Williams), de um filho de operário (E. P. Thompson) e do filho de um ferroviário (Richard Hoggart), fundadores do Centre for Contemporary Cultural Studies nos anos de 1960. Posteriormente, os estudos culturais britânicos influenciaram teoricamente a abordagem dos estudos de recepção na América Latina, nos anos de 1990, a partir do receptor enquanto sujeito ativo do processo comunicacional.
} 
Institucional de Investigación en Comunicación y Prácticas Sociales (Universidad Iberoamericana, México. (JACKS, 1993, p.44).

A preferência pelos autores latino-americanos ocorreu por eles postularem a existência do emissor e do receptor em uma relação mediada pelo contexto, pelas instituições e pela cultura, abordando o receptor a partir de suas mediações. Dentre esses autores, três correntes ganharam mais espaço que as outras: o "consumo cultural" (Néstor García-Canclini), o "uso social dos meios" (Jesús Martín-Barbero) e o "enfoque integral da audiência" (Guillermo Orozco Gomez). A primeira se baseou em uma teoria sócio-cultural do consumo para abordar os processos de comunicação e recepção de bens simbólicos. A segunda articulou as práticas de comunicação aos movimentos sociais, tendo o foco no popular em seu convívio com o processo de modernização e os usos do receptor em face do massivo. E a terceira perguntou quais as mediações surgem na produção de sentidos do receptor enquanto audiência televisiva, imerso em determinado contexto (JACKS et.al., 2008).

Tal perspectiva aporta no Brasil sob uma conjuntura de crítica teórica e política do difusionismo, que apregoava a comunicação vertical do pólo do emissor para o pólo do receptor. Os estudos de recepção de viés latino-americano procuraram desvendar o sujeito oculto nesse receptor, pois o mesmo se definia anteriormente pelo ponto de vista do emissor. Contudo, os estudos de recepção - na tentativa de se contrapor ao modelo político instrumental dos meios de comunicação da época - apenas inverteram o pólo, agora partindo do ponto de vista do receptor e mantendo o modelo vertical de comunicação: "Linearidade ao inverso, uma ênfase excessiva no receptor, uma valorização indiscriminada dos usos, assim como uma fragmentação da abordagem e uma sociologização dos estudos de recepção em detrimento da apreensão do processo e do próprio enfoque comunicacional (FRANÇA, 2004, p.35).

Este foco no sujeito se deve à influência dos pesquisadores do Ciespal, que conceberam a recepção como uma terceira via a partir de processos "de baixo para cima", na busca de identificar a resposta dos receptores em sua cultura subalterna popular, na articulação complexa com o massivo e com a cultura hegemônica situadas em um contexto macro. A chamada "chave para a recepção" tinha como missão apenas libertar o sujeito oculto no receptor. Em nome dessa visão política, Martín-Barbero (1984) não se incomodou em ser visto como um culturalista no meio acadêmico e propôs "perder o objeto para ganhar o processo". Alguns autores 
advertiram sobre os riscos desta pulverização do objeto da comunicação e do escletismo teórico-metodológico nos estudos de recepção (LOPES, 1997).

Em um trabalho exaustivo de levantamento das pesquisas em recepção no Brasil, Jacks et.al. (2008) apresenta três abordagens dos estudos: dois se destacam na década de 1990 (as abordagens sociocultural e a comportamental) e outra surge nos anos 2000 (a abordagem sócio-discursiva). A primeira permitiu associar cultura e comunicação em complexidades de nível macro, onde os sujeitos e seus grupos se articulam em várias relações sócio-culturais além da recepção dos meios em si; a segunda considerou o produto midiático um estímulo, motivando variadas respostas dos públicos, como por exemplo, estudos de formação de opinião, dos efeitos cognitivos e dos usos e gratificações, que levou em conta a audiência, dentro da tradição funcionalista de entender os "efeitos" da mídia sobre os sujeitos.

Estas abordagens dos anos de 1990 permitiram estudos do sujeito receptor em seu cotidiano, metodologias etnográficas da audiência, análise da identidade cultural, das classes sociais, identificação de mediações culturais e das diferenças de gênero. $O$ receptor no final dos anos 90 era apreendido por uma leitura menos ideologizada $^{17}$, e entendido como um sujeito mais ativo e negociando em seu cotidiano com outros significados instituídos na sociedade antes e depois do contato com as mensagens midiáticas, interpretando e fazendo uso das mensagens e permitindo pactos de recepção; as mediações eram múltiplas, assim também os emissores, as articulações e os diferentes receptores; e muito pouca pesquisa em recepção havia sido produzida sobre o público do meio rural (JACKS et al., 2008; JACKS E SOUZA, 2006; ESCOSTEGUY e JACKS, 2006).

Mas por outro lado, a complexidade da coleta e da inferência nos dados para o estudo da recepção, o desgaste de pesquisas que reproduziram sem crítica os mesmos autores, algumas sem fazer referência às pesquisas dos principais autores brasileiros, parecem ter sido causas do arrefecimento das pesquisas em recepção na última década.

\footnotetext{
${ }^{17}$ A visão ideologizada do receptor surge vinculada à crítica ideológica do Ciespal ao difusionismo nas décadas anteriores, que enxergou o foco das pesquisas no receptor como uma visão parceira da perspectiva da "terceira via" em face de processos políticos "de cima para baixo". Até os dias atuais, alguns movimentos sociais ainda observam os veículos de comunicação de massa como subjugadores da cultura subalterna e popular, conservando receptores ideologizados dentro de processos comunicacionais "horizontais" que servem para as suas próprias causas políticas.
} 
Se ao iniciar a década de 90 , no contexto acadêmico brasileiro, detectava-se um entusiasmo com a problemática da recepção, a entrada neste novo milênio possivelmente indicaria uma retração. Não há ainda levantamentos que comprovem tal tendência, apenas sintomas. Depois de estar em evidência, por um curto período, a energia que atravessava os estudos de recepção arrefeceu (ESCOSTEGUY, 2008, p.1).

A perspectiva da recepção contribuiu para a compreensão dos processos culturais e comunicacionais, mas não se desenvolveu além de suas próprias teorias e autores, deixando um pouco de lado as condições de produção do texto midiático em relação aos da recepção. Além do problema de negligenciar o próprio texto, os estudos de recepção encontraram desafios diante das crescentes situações sociais mediatizadas tecnologicamente (a presença e a influência mais intensa das diferentes mídias eletrônicas) proporcionadas pelo aumento e melhoria das malhas de telecomunicações e acesso às redes sociais na internet.

Essa conjuntura gerou uma recepção difusa ou dispersa ${ }^{18}$ : no campo da produção, ampliaram-se as opções de programas, telenovelas, telejornalísticos, transmissões esportivas; no campo da recepção, cresceram outras formas de complementação de mídias, surgiram às conversações midiáticas, novos gostos e costumes mediatizados tecnologicamente. Borram-se as fronteiras entre receptor e emissor, ganham em importância as relações horizontais da comunicação e, nisto, importam as intensas trocas comunicativas entre os sujeitos e a possibilidade de fazer circular informação da televisão às redes sociais.

Buscando talvez uma saída, Rocha e Marques (2006) propuseram destacar os diálogos dos estudos de recepção com as lógicas e os modos de operar no âmbito da produção, apontando a possibilidade de investigação dos significados entre produção e recepção no processo comunicativo. Ao lembrar o lugar da produção no estudo de recepção, as autoras iluminaram o caminho rumo à interseção entre os campos da produção e da recepção. "Por isso consideramos a interseção um lugar mais rico de análise, pois além de podermos evidenciar os conflitos de informações, as diferentes motivações, veremos que tal processo é complexo, pois envolve

\footnotetext{
${ }^{18}$ Segundo José Luiz Braga (2010), na mediatização as mídias se oferecem dispersas (ou difusas) em possibilidades informacionais. Isso permite observar também uma recepção mais difusa (ou dispersa) nas várias possibilidades do sujeito em experienciar múltiplas mensagens midiáticas. Mas as interpretações e os usos mediatizados levam em consideração o olhar do receptor: o olhar do público pode estar preparado ou não para oferecer aos produtos da mídia uma formação prévia reflexiva.
} 
vários atores, um cenário contextual, um texto [ou vários textos] e múltiplas interpretações" (ROCHA; MARQUES, 2006, p. 37).

No âmbito dos textos publicados no GT da Compós "Recepção: processos de interpretação, uso e consumo midiáticos" ${ }^{19}$, ainda são tímidas as iniciativas em direção a uma reformulação dos velhos conceitos atrelados aos estudos de recepção, bem como poucos os artigos que propõem aos estudos uma abordagem comunicativa. Natansohn (2007) indagou até onde velhos conceitos importantes aplicados nos estudos da recepção dão conta de explicar o consumo de novas mídias hoje: "Podemos continuar utilizando os esquemas conceituais que desde 1980 norteiam os estudos sobre audiências, voltados, principalmente, para o público da televisão e preocupados com questões vinculadas ao sentido, às identidades e ao poder?" (p.3).

Outros autores, como Adriana Braga (2008), ao mostrar as interatividades em um weblog e a circulação das mensagens por meio de diferentes articulações e complementaridades com outras mídias, põe em dúvida o próprio termo "recepção". No ano seguinte, resumindo temas e conceitos propostos por autores da Escola de Chicago, Braga e Gastaldo (2009) explicam que a perspectiva interacional pode auxiliar o estudo da recepção a partir de fenômenos comunicacionais, onde os meios de comunicação ganham destaque ${ }^{20}$.

Jacks et.al. (2012) classifica de "abordagem sóciodiscursiva" os trabalhos em recepção produzidos na década de 2000. Tais pesquisas mostram alguns aspectos significativos: a temática das identidades não tem grande destaque e desaparecem as citações a autores como García-Canclini e Orozco; crescem temas relacionados à participação do leitor e à relação entre emissãorecepção via teorias do discurso e da semiótica; aumenta o número de citações de outros autores (como Foucault, Bakhtin, de Certeau, Bauman, Orlandi, J.L. Braga e Lúcia Santaella), que juntas superam

\footnotetext{
${ }^{19}$ Pesquisamos no site da Compós os artigos do GT "Recepção, Usos e Consumo Midiático" do ano de 2007 até 2011 e não identificamos nenhum artigo com o objeto de estudo o "rural" ou "juventude rural". Ressaltamos apenas que Coelho (2011) apresentou trabalho sobre a apropriação das interfaces digitais na ambiência juvenil urbana, problematizando sentidos de pertencimento, subjetividades e formações socioeconômicas no processo de midiatização e na transformação das relações de cotidiano. O primeiro trabalho neste GT sobre mídia e juventude rural é o de Duarte e Soares (2012).

${ }^{20}$ Aqui é importante salientar algo que parece fugir aos conhecimentos dos autores: a abordagem praxiológica da comunicação de Luis Quéré (1991), que é uma perspectiva interacional na qual leva em conta basicamente uma comunicação no centro da vida das pessoas; e a linguagem dos meios se constitui na relação dos sujeitos na/da comunicação (FRANÇA, 2006).
} 
o número de vezes em que Martín-Barbero é citado nos trabalhos. No geral, os estudos de recepção da última década não trouxeram novidade quanto a uma saída epistemológica para os estudos de recepção, sem problematizar os conceitos advindos com as novas mídias e a nova realidade sociocultural trazida pela internet, também sem enfrentar os processos de interação fora da web e a lógica da convergência midiática. "Ainda quando a interação é apenas uma possibilidade, as práticas de recepção podem estar sendo transformadas, o que implica na reconfiguração dos estudos como um todo, em termos teórico, metodológico, temático, político, etc" (JACKS et al., 2011, p.94). Para Jacks et.al. (2012), torna-se inadiável a discussão sobre a nomenclatura do termo "recepção" em função da urgência no enfrentamento da nova realidade de produção/circulação/consumo dos conteúdos midiáticos.

\section{3. À GUISA DE UMA CONCLUSÃO: EM BUSCA DE UM OUTRO LUGAR TEÓRICO-EPISTEMOLÓGICO}

No grupo de trabalho sobre "Recepção: processos de interpretação, uso e consumo midiáticos", que se reúne anualmente nos encontros da Associação Nacional dos Programas de PósGraduação em Comunicação (Compós) ${ }^{21}$, a perspectiva que apontou uma saída mais interessante do pólo da recepção na direção de uma "abordagem comunicativa" foi a de Fausto Neto (2012). As mensagens circulam pelas bordas do consumo de mídia, dando existência a novos desenhos de organização e funcionamento dos processos de circulação, objetos centrais da comunicação (FAUSTO NETO, 2010, 2012). Para o autor, os impactos dessas novas disposições midiáticas da mensagem sobre o âmbito da recepção suscitam uma revisão do termo "recepção", pois o mesmo se vincula ao resultado dos efeitos ou à confirmação das expectativas dos pólos emissores. A ação "tecnosimbólica" do campo da produção sobre o campo da recepção não se efetiva de modo causal, de acordo com a intenção dos sujeitos nesta relação, como se essa intenção determinasse por si a ocorrência de comunicação ${ }^{22}$.

As relações entre produção e recepção estavam situadas fora da ocorrência do ato de comunicação, sem levar em conta a

\footnotetext{
${ }^{21}$ Grupo de Trabalho dos encontros anuais da Associação dos Programas em PósGraduação em Comunicação (www.compos.org.br).

${ }^{22}$ Ressaltamos que Jacks e Silva (2011) fizeram um levantamento das pesquisas em recepção entre os anos de 2000-2002 revelando a tendência em alguns trabalhos em buscar uma relação da mensagem midiática com a vida cotidiana das pessoas, apesar da maioria das pesquisas terem o foco mais no receptor do que em uma relação da mensagem com o receptor.
} 
complexidade e a incerteza do processo comunicativo. A ênfase estava na consciência do receptor no processo, colocando fora de cena a circularidade da informação. O que existe é uma área de fluxo produção/recepção que foi visto anteriormente como uma mera passagem automática do processo (FAUSTO NETO, 2010).

Portanto, trazemos os estudos das interações comunicativas para os estudos rurais propondo que os pesquisadores interessados no estudo dos sujeitos no território da recepção observem a perspectiva da abordagem comunicacional que leva em conta esse lugar da circulação das mensagens chamado por Fausto Neto (2010) de "zona de interpenetração" ou o instante da ocorrência de comunicação quando populações rurais são afetadas pelo conteúdo da mídia, seja reverberando os assuntos em seus espaços de socialização, mudando hábitos de consumo, jeitos de ser e indumentária ou produzindo mensagens nos meios sob a influência das mídias.

Nesta perspectiva interacionista - já adotada por importantes pesquisadores no campo da comunicação (FRANÇA, 2004a, 2004b, 2006, 2008; BRAGA, 2010, 2012; PINTO e SERELLE, 2007) - os territórios da recepção e da emissão se posicionam lado a lado e, com o foco nesta "interpenetração", importa menos o ajuste de lentes no sujeito do discurso ou nas representações da linguagem do que, em primeiro lugar, na ocorrência da comunicação ${ }^{23}$. O intercruzamento de sentidos no espaço conflituoso da "interpenetração" constrói a comunicação por meio de instantes que se fazem e se refazem na experiência dos sujeitos na situação, ora como emissores ora como receptores. "Em suma: uma perspectiva interacional e situacionista não permite analisar uma fase do ato social sem levar em consideração seu encadeamento numa sequência de outras fases" (FRANÇA, 2008, p.85).

Trata-se de outro lugar epistemológico em relação aos atuais estudos de recepção. A consolidação deste lugar não significa rompimento nem se arvora em apresentar-se enquanto uma possibilidade de transformação dos estudos. Dentro do espectro das epistemologias que são adotadas nas pesquisas em recepção, o lugar das interações comunicativas torna visível uma matriz teórico-

\footnotetext{
${ }^{23}$ As interações sociais são o lugar de ocorrência da comunicação, por isso não se trata apenas da decodificação e do convencimento do sujeito no território da recepção, mas sim da produção de sentidos no momento da relação. A comunicação se faz como resultado de um trabalho social e humano na direção de produzir algo que não está dado de forma prévia a interação (BRAGA, 2010). Se desenvolvimento rural significa mudança, a mudança ocorre através de processos comunicacionais.
} 
metodológica própria, ampla e eficaz que procura explicar aquilo que interessa à área da comunicação, a abordagem comunicativa.

Observa-se o nível macro da complexa relação entre os territórios da recepção e da emissão, mas igualmente o universo micro das relações situacionais que constituem as interações dos sujeitos com os conteúdos midiáticos e suas formas de reverberação nos espaços de socialização. Por essa saída, tratamos a comunicação situada no centro da vida e não de forma instrumental e representacionista. Os discursos se entrelaçam na experiência dos sujeitos no cotidiano, em ambos os territórios; a interação se faz e refaz na base da sociedade e permite que as linhas de força dos discursos da mídia sejam reconfigurados, atualizados e resignificados no cotidiano, a partir das experiências dos sujeitos no contato social.

Ao deslocarmos as preocupações da comunicação para a relação no centro da vida, temos que mudar nossa forma de pensar o objeto de estudo e a vida social. Temos que observar como as pessoas do rural estão engajadas e se mobilizam em uma ação de se comunicar a partir do contato social e uma comunicação na vida. O processo comunicacional seria tanto o lugar de constituição dos espaços e dos fenômenos sociais quanto à produção da comunicação entre seus membros e "dos quadros institucionais que garantem sua identidade e sustentam sua ação” (QUÉRÉ, 1991).

A comunicação na vida das pessoas atua enquanto construção social da realidade e, neste sentido, interessante os atravessamentos: da forma (a objetividade) com o sentido (a subjetividade); da atividade dos sujeitos com seus engajamentos na realidade comum; da função representativa da linguagem com sua função expressiva e constitutiva. Se a comunicação está em todas as atividades práticas cotidianas da vida, então implica em uma mudança de paradigma com relação às pesquisas.

O esforço, então, está na substituição do modelo representacionista-informacional da comunicação por um modelo propriamente comunicacional. Quéré (1991) sugere uma concepção praxiológica da comunicação, articulada ao problema da realidade que se constrói a partir da intersubjetividade e da constituição da linguagem, da expressão e da cognição no plano situacional.

Não importam as intenções prévias no projeto político de comunicação ou do programa de rádio e televisão. Nem as intenções que se encontram no território da emissão, nem as que se alocam no território da recepção, determinam o que vai acontecer. Importa, sim, ter a construção na relação, no momento da fala e da ação, instante 
do intercruzamento de sentidos neste espaço semântico e prépolítico da recepção.

\section{REFERÊNCIAS BIBLIOGRÁFICAS}

ARAÚJO, C.A. A pesquisa norte-americana. In: HOHFELDT, Antonio; et.al. (Orgs.). Teorias da comunicação: conceitos, escolas e tendências. Petrópolis: Vozes, 2001.

ARENDT, H. A condição humana. 10 ${ }^{\underline{a}}$ Ed. São Paulo: Forense Universitária, 2005.

BERLO, D.K. Communication theory and audiovisual instruction. Keynote Address to the National Convention of the Departament of Audiovisual Instruction. National Education Association: Denver/Colorado, April 23,1963.

BELTRÁN, L.R. Adeus a Aristóteles: comunicação horizontal. Comunicação e Sociedade, n.6, p. 5-35, set. 1981.

BERELSON, B; STEINER, G. Human Behavior. New York: Harcourt, 1964.

BORDENAVE, J.D. O que é comunicação rural? São Paulo: Brasiliense, 1983.

Comunicação Rural: discurso e prática. IN: BRAGA, G.M.; KUNSCH, M.M.K. (Orgs.). Comunicação Rural: discurso e prática. XI Congresso Brasileiro de Estudos Interdisciplinares da Comunicação - 1988. Viçosa/MG: Editora Universitária, 1993, p.1121.

BLUME, R. Território e ruralidade: A desmistificação do fim do rural. Porto Alegre: FCE, 2004.

BRAGA, J.L. Nem rara, nem ausente - tentativa". Revista Matrizes, Ano 4, o 1, jul/dez. São Paulo: ECA/USP, p. 65-81, 2010.

.Interação como contexto da comunicação. GT Epistemologia da Comunicação, XXI Encontro da Compós em Juiz de Fora/MG, 2012. 
BRAGA, A.A.; GASTALDO, E. O legado de Chicago e os estudos de recepção, usos e consumos midiáticos. GT Recepção: processos de interpretação, uso e consumo midiáticos, XVIII Encontro da Compós em Belo Horizonte/MG, 2009.

BRAGA, A.A. Complementaridade das mídias: usos sociais da internet e seus precedentes. GT Recepção: processos de interpretação, uso e consumo midiáticos, XVII Encontro da Compós em São Paulo/SP, 2008.

BRAGA, G.M.; KUNSCH, M.M.K. (Orgs.). Comunicação Rural: Discurso e Prática, Viçosa: UFV, 1993,173p.

CALLOU, A. F.B. A pesquisa em comunicação rural na Intercom 1991/2000. Trabalho apresentado no XXIV Congresso Brasileiro da Comunicação da Sociedade Brasileira de Estudos Interdisciplinares da Comunicação em Campo Grande /MS, setembro de 2001.

CALLOU, A. B. F. (Org.) Comunicação rural, tecnologia e desenvolvimento local. São Paulo: Intercom, 2002.

CALLOU, Â.B.F.; TAUK SANTOS, M.S. Desafios da Comunicação Rural em tempo de Desenvolvimento Local. Revista de Comunicação Integrada - SIGNO. Ano II, n.3, João Pessoa UFPB, Setembro de 1995.

CARNEIRO, M. J. O ideal rurbano: campo e cidade no imaginário dos jovens rurais. IN: SILVA, F.C.T. da. SANTOS, R.C.; COSTA, L.F.C. (Orgs.). Mundo rural e política: ensaios interdisciplinares. Rio de Janeiro: Campus, 1998, p.97-117.

. Juventude Rural: projetos e valores. IN: ABRAMO, H.W.; BRANCO, P.P.M. (Orgs.). Retratos da juventude brasileira: análises de uma pesquisa nacional. São Paulo: Fundação Perseu Abramo, 2005, p.243-262.

DUARTE, R.; SOARES, J.B. Consumo de mídias eletrônicas, interações e valores entre jovens rurais mineiros. Trabalho apresentado ao Grupo de Trabalho "Recepção, Usos e Consumo Midiáticos" do XXI Encontro da Associação Nacional dos Programas de Pós-Graduação em Comunicação (Compós), na Universidade Federal de Juiz de Fora, Juiz de Fora, de 12 a 15 de junho de 2012. 
ESCOSTEGUY, A.C. Quando a Recepção já não alcança: Por uma revisão no objeto e método. GT Recepção: processos de interpretação, uso e consumo midiáticos, XVII Encontro da Compós em São Paulo/SP, 2008.

FAUSTO NETO, A.; SGORLA, F. Despedindo-se de Fátima (do Jornal Nacional?): "...vamos ficar órfão (...)": o JN fica sem sentido... GT Recepção: processos de interpretação, uso e consumo midiáticos, XXI Encontro da Compós em Juiz de Fora/MG, 2012.

FAUSTO NETO, A. Bordas de circulação... Revista Alceu, v. 10, n.20, p. 55-69, jan./jun de 2010.

FIGUEREDO, R.P. A extensão rural no Brasil. Santa Maria: UFSM, 1981. Palestra apresentada ao Curso de Pós-Graduação em Extensão Rural da UFSM-RS. (mimeo).

FRANÇA, V.R.V. Interações comunicativas: a matriz conceitual de G.H.Mead. In: PRIMO, A.; et al. Comunicação e Interações. Porto Alegre: Sulina, 2008, p. 16-21.

Representações, mediações e práticas comunicativas. In: PEREIRA, M.; GOMES, R.C.; FIGUEIREDO, V.L.F. Comunicação, representação e práticas sociais, 2004a, p.13-26.

Programas populares na TV: desafios metodológicos e conceituais. GT Cultura das Mídias, XIII Encontro da Compós em São Bernardo do Campo/SP, 2004b.

Sujeitos na, sujeitos em comunicação. In: GUIMARÃES, C; FRANÇA, V.R.V. (orgs.). Na mídia, na rua: narrativas do cotidiano. Belo Horizonte: Autêntica, 2006, p.61-88.

Apostila do Curso Básico de Teorias da Comunicação. Belo Horizonte: UFMG, 2003.

FREYRE, G. Rurbanização: Que é? Recife: Editora Massangana, 1982.

GOMES, I.M.M. O Conceito de Recepção e a Abordagem do Processo Comunicativo. Textos de Comunicação e Cultura, no 36 , Salvador dezembro de 1996, p.17-36. 
GRAZIANO, J. "Por um Novo Programa Agrário". Revista da Associação Brasileira de Reforma Agrária (ABRA). Volume 23, No 2. São Paulo, maio/ago de 1993, p. 5-16.

A Nova Dinâmica da agricultura brasileira. Campinas: IE/UNICAMP, 1996, p. 41-190.

O Novo Rural Brasileiro. Revista Nova Economia. Departamento de Ciências Econômicas da UFMG. Volume 7, No 1. Belo Horizonte, maio de 1997, p. 43-82.

GRAZIANO, J. CAMPANHOLA, C. "Diretrizes de Políticas Públicas para o Novo Rural Brasileiro: incorporando a noção de desenvolvimento local”. O Novo Rural Brasileiro: Políticas Públicas. Jaguariúna/SP: EMBRAPA/Meio Ambiente, vol. 4, 2000. Nota pé, p.139.

JACKS, N. A recepção na querência, estudo da audiência e da identidade cultural gaúcha como mediação simbólica. Tese (Doutorado em Ciência da Comunicação). ECA/USP, 1993.

JACKS, N.; MENEZES, D.; PIEDRAS, E. Meios e audiências: a emergência dos estudos de recepção no Brasil. Porto Alegre: Sulina, 2008.

JACKS, N; SOUZA, M.C.J. de. (Orgs.). Mídia e recepção: televisão, cinema e publicidade. Edufba: Salvador/BA, 2006.

JACKS, N.; JOHN, V.M.;SILVA, L.A.P. Estudos de recepção no Brasil:panorama da última década. GT Recepção: processos de interpretação, uso e consumo midiáticos, XXI Encontro da Compós em Juiz de Fora/MG, 2012.

JACKS, N.; et. al. Pesquisa sobre audiências midiáticas no Brasil: primórdios, consolidação e novos desafios. In: JACKS, N..; MARROQUIN, A.; VILLARROEL, M.; FERRANTE, N. Análisis de recepción en América Latina: un recuento histórico con perspectivas al futuro. Quito: Ciespal, 2011.

JACKS, N. et al., Pesquisa sobre audiências midiáticas no Brasil: primórdios, consolidação e novos desafios. In: JACKS, N.; MARROQUIN, A.; VILLARROEL, M.; FERRANTE, N. (Orgs.). Análisis Del Recepción em América Latina: un recuento 
histórico con perspectivas al futuro.Quito/Ecuador: Ediciones Ciespal, 2010, p.69-102.

JACKS, N.; SILVA, L.A.P. Recepção de telenovela: a pesquisa brasileira no nascer do século XXI. Revista Alaic, 2011, n. 8-9, p. 252-262.

LERNER, D.; SCHRAMM, W. Comunicação e mudança. IN: LERNER, D; SCHRAMM, W. Comunicação e mudança nos países em desenvolvimento. São Paulo: UNESP, 1973.

LOPES, M.I.V.de. O estado da pesquisa em comunicação no Brasil. In: Temas contemporâneos de comunicação. São Paulo: Intercom, 1997, p.13-27.

MARTÍN-BARBERO, J. De La comunicación a la cultura. Perder el objeto para ganar el proceso. Signo y Pensamiento, n. 5, vol. 3, ano 3, Bogotá: Universidad Javeriana, 1984.

NAVARRO, Z. Extensão rural no mundo. Viçosa: UFV, 2012. Palestra de abertura do semestre apresentada ao Curso de Mestrado e Doutorado em Extensão Rural da UFV-MG. (gravado).

NATANSOHN, G. Estudos de recepção nas novas mídias. GT Recepção: processos de interpretação, uso e consumo midiáticos, XVI Encontro da Compós em Curitiba/PR, 2007.

NUNES, L. N. E. Discussão sobre difusão e adoção de inovações na agricultura. Brasília, 1977. Dissertação (Mestrado pela Universidade de Brasília), 1977. O estudo apresenta Brasil, Colômbia e México como sendo os países que estimularam a maioria dos estudos na área da difusão de inovações na agricultura.

OSGOOD, C.E. Television and the teaching of English. New York: Appleton-Century, 1961.

PINTO, J.; SERELLE, M (Org.). Interações midiáticas. BH: Autêntica, 2007.

POOL, De Sola. Le rôle de la communication dans le processus de la modernisation et du changement technologique. In: HOSELITZ, B. MOORE, W. (orgs.) Industrialisation et Societé, UNESCO. Paris: 1963. 
QUÉRÉ, L. "D'um modele épistemologique de La communication à um modele praxéologique". Réseaux, Paris: Tekhné, 46/47, p.6990, mar-abril, 1991.

ROCHA, S.M.; MARQUES, A.C.S. A interseção do processo comunicativo. In: JACKS, N.; SOUZA, M.C.J. de. (Orgs.) Mídia e Recepção: televisão, cinema e publicidade. Salvador: EDUFBA, 2006, p. 32-55.

TAUK SANTOS, M. S. Igreja e pequeno produtor rural: a comunicação participativa no programa Cecapas/Serta. São Paulo, 1994. Tese (Doutorado em Comunicação). ECA/USP, 1994.

Comunicação e Consumo: espaço das mediações da cultura transnacional e das culturas populares. INTERCOM Revista Brasileira de Comunicação, São Paulo volume XIX, n.2 pag. 35-48, jul./dez. 1996.

Comunicação rural: velho objeto e nova abordagem: mediação, reconversão cultural e desenvolvimento local. Colóquio Brasil-França de Ciência da Comunicação. Recife, setembro de 1998.

SANTOS, R. Rurbanização e revolução agrária em dois registros clássicos. Revista Estudos Sociedade e Agricultura, n.16, abril 2001, p.74-93.

SOUSA, M. W. (Org.). Sujeito, Sujeito o lado oculto do Receptor. São Paulo: Brasiliense, 1995.

SOROKIN, P. A.; ZIMMERMAN, C.C.; GALPIN, C. J. Diferenças Fundamentais entre o mundo rural e urbano (1929). IN: MARTINS, J. S. Introdução Crítica à Sociologia Rural. São Paulo: Hucitec, 1986.

SIQUEIRA, D.; OSÓRIO, R. O conceito de Rural. IN: GIARRACA, N. (Org.). Una nueva ruralidad en América Latina? Ciudad Autónoma de Buenos Aires, Argentina. 2001, p.67-79.

SOLARI, A. B. O Objeto da Sociologia Rural. In: SZMRECSÁNYI, T.; QUEDA, O. (orgs.). Vida Rural e Mudança Social. São Paulo: Companhia Editora Nacional, 1979. 
TOLEDO, V. M. Estudiar lo rural desde una perspectiva intersdisciplinaria: el enfoque ecológico-sociológico. In: Globalización, crisis y desarrollo rural en América Latina: Memória de sesiones plenárias, México: Universidad Autónoma Chapingo-Colégio de Postgraduados, 1998.

VEIGA, J.E. Cidades Imaginárias. O Brasil é menos urbano do que se calcula. Campinas: Editora Autores Associados, 2002.

Paulo, 2004 (base Scielo).

Nem tudo é Urbano. Ciência e Cultura, v.56, n.2, São

WANDERLEY, M. de N. B. A ruralidade no Brasil moderno. Por un pacto social pelo desenvolvimento rural. IN: GIARRACCA, N. ¿Una nueva ruralidad en América Latina? Buenos Aires: Consejo Latinoamericano de Ciencias Sociales (Clacso), 2001. 